\title{
The Position of the Niqab (the Face Veil) in Australia under Australian and Islamic Laws
}

\author{
Asmi John Wood
}

\begin{abstract}
The Sayed Case in the District Court of Western Australia required the court to decide on the issue of a witness in niqab. The defendant, in this case a Muslim man, said that a prosecution witness wearing niqab created a disadvantage for the defense and wanted her to provide her testimony without a face veil. While this is a narrow characterization of the issue for the court, the case sparked much controversy including calls for the government to regulate forms of Muslim women's dress as was the case in France and Belgium. At present, while many Muslim women in Australia do not cover either their hair or face, the common law and statute do not prescribe or proscribe any form of dress for Australians.

The call by some Muslims, such as in the Sayed Case, for the imposition of limits on Muslim dress, employs the scholarship of foreign Muslims who they support. This paper calls for the rejection of such prescriptive formulations of both Australian law and the local expressions of Islamic law. Others such as Katherine Bullock, an Australia Muslim academic, support women's choice in the broadest terms - and this paper supports the primary sources of Islam, the traditional Islamic scholarship, and is deeply acculurated in the Australian ethic of personality autonomy and choice for all, including
\end{abstract}

\footnotetext{
Asmi J. Wood is a barrister and solicitor in the Australian Capital Territory. He teaches in the Australian National University Law Program. His PhD was on comparative aspects of the use of force between the Shari ${ }^{-}$ah and international law.
} 
Muslims women. While they are both independent works, both Bullock's work and the common law as articulated by the judge in the Sayed Case are strongly supportive of allowing women the choice of covering themselves. This paper contends that Australian common law, as confirmed in the Sayed Case, is reflective of a broader Muslim consensus and should be retained as the status quo.

\section{Introduction}

Public expressions of faith or culture, particularly with respect to recently arrived immigrant groups can raise disquiet in some segments of Australian society. Novel cultural issues with which Australians have had to recently contend include female genital mutilation among some immigrant African and Asian groups, forced marriages among West Asians, and unusual dress items such as saris and head and face covers. Since the September 11 attacks, head covers of Muslim women also appear to have increasingly touched on the sensitivities of a broader range of Australians.

Although I focus ultimately on Muslim women's face cover (the niqab), it necessarily touches upon the headscarf (the hijab) concepts that are often conflated in the debate on the niqab in the public space. I examine the legal position on the wearing of a head covering and in some cases including a face cover in Australia. Moroccan scholar Fatema Mernissi's view, that many traditional Muslim women will abandon the veil when given the opportunity, appears to be borne out by the practice of many immigrant Muslim women. ${ }^{1}$ The possible reason for this phenomenon is that many first generation immigrants in Australia hail from oppressive societies that fit within Mernissi's social framework; they are usually more focused on economic betterment and, therefore, take much longer to become comfortable with Australia's civil and political freedoms, including the right to manifest symbols of one's faith in public.

On the other hand, Mernisi's position on the head cover - and cognizant that it is quite unlikely that she would have consciously contemplated Australian conditions in her works - appears to be unnecessarily self-limiting in the Australian context. The first concern in this regard is that deference in the West to Mernissi's views on head cover results in Australian Muslim women converts by default being influenced by a position formulated in the main to address very different historical, legal, and social circumstances. Given the difficulties of information overflow in the initial stages of conversion, this deference is unhelpful and can in cases deny Muslim converts the option of an informed choice on what is at least an important symbolic issue. 
The crucial longer-term disadvantage is that because Muslim immigrants and their families still make up, and in the foreseeable future are likely to make up the vast majority of the Australian Muslim community their majoritarian views are largely, although not exclusively informed by economics rather than by theology or law - a great disservice because Islam is directly connected to law but only incidentally with respect to a capitalist economic system. ${ }^{2}$ Further, through this majoritarian push, Mernisi's views - and through no fault of hers - but through the sometimes poorly informed nature of community debate, appears disproportionately to influence other Australians interested in Muslim women's issues.

Thus, the current position in Australia - that is, that Muslim women appear largely not to cover except on significant religious events, which while it accords with Mernissi's position, is not entirely in accordance with Islamic law.

In the examination of the Sharī'ah vis-à-vis Australian law, and as shown below, the relevant aspects of the Shari' $a$ ah can lawfully be examined anew- and therefore, should, free of many of the oppressive conditions influencing Mernissi's thesis. This examination also attempts to balance the debate dominated by majoritarian issues and interests. Although the position of Katherine Bullock, an Australian scholar, on the head cover is not directed at Australians; nevertheless, her work could nonetheless reasonably be said to contemplate such an audience - and is compared vis-à-vis to both the Sharī'ah status quo and, importantly, to its practical application under Australian law.

I propose that Bullock's view that hijab has a firm Islamic legal basis (that is, its adoption is advocated by the majority of Islamic scholars and many Muslim women globally); also the Australian community must rethink its position particularly with respect to its contemporary legitimacy and utility (Bullock's position), which is the better presumptive position for the development of Australian custom on this personal law matter. Bullock's position is diametrically opposite to that of Mernissi, at least on the issue of the desirability of hijab for women. Bullock's position, however, is truer to the primary sources of Islamic law, the Qur'ān and the Sunnah and, in the Sharī'ah tradition, respects the development of the issue based in the jurisprudence, law, and precedent.

Broadly speaking, there are at present no legal sanctions for adherence or breach of any purely religious dress code obligations in Australia for Muslims or members of any other faith. There are, however, some practical limitations that I will discuss. I argue for maintaining the legal status quo on this issue and suggest that legal sanctions in Australia should not be contemplated for niqab, hijab, burqa, chādor, or other forms of Muslim 
women's dress. ${ }^{3}$ This general Anglophone position can be contrasted with say the position in Belgium or France where wearing the niqab (le viole intégrale) in public places is against the law and is a measure that is supported by the majority in those countries. ${ }^{4}$ Further, even the use by Muslim women of the hijab (le foulard) in public places is also is restricted by law. ${ }^{5}$

In addition to legal sanctions, Muslim women may also face social sanctions (including by some Muslims) for the individual adherence to or breach of Islamic social norms. Although very uncommon, women's hijabs have purportedly been pulled off women on the streets of Sydney. ${ }^{6}$ Such behavior is reprehensible and is considered unacceptable by the majority of Australians. Consequently, this ugly practice is very uncommon and is limited to particular segments of society, such as among the far right or even Nazis who are on the whole quite hostile to non-English social norms, especially against such highly visible symbols. ${ }^{7}$

Without minimizing their human impact and effect, people with antisocial behavior should be addressed through education and civil sanctions rather than the blunt instrument of the criminal law - however, they should be cognizant that international law requires the enactment of domestic laws against discriminatory behavior. ${ }^{8}$ In general however, in Australia, Muslim women's dress is subject to a degree of public attention that far exceeds its actual legal importance or the breadth of such practice.

I attempt to identify and influence emerging Islamic norms on Muslim head covers in Australia. I also approach the niqab issue from an Islamic law, international law, common-law, and an Australian social perspective in order to encourage the community to develop an Australian Shari' ah, and a legal and community consensus position on Islamic dress - and importantly to do so in concert with all these laws.

Based on the practice of a segment of Australian Muslim women, I examine the legal social implications for Australian Muslim women wearing niqab and, in instances, the hijab. Some of the evidence used is anecdotal. The reference to anecdotal evidence is unfortunate, but the collection of statistics based on religious affiliation is traditionally difficult in Australia - but is nonetheless an important gap in information that must be correctly and lawfully collected, collated, and analyzed as an urgent task. ${ }^{9}$

The broader call in this paper is for the development of Islamic law in Australia, to encourage the development of a uniquely Muslim identity, and to prevent the almost total assimilation of Muslims - as has happened in the past in Australia to the Makassars, Afghans, Syrians, and other denizens who have "disappeared," but who have left tantalizing traces of their lives. ${ }^{10} \mathrm{I}$ also seek more broadly to promote and encourage the develop- 
ment and crystallization through local consensus of Sharī'ah personal law - legal opinions that will be available to all Australians. And for reasons that will become clear, this development will contribute positively to the development of the law as it affects Muslims, thereby helping to solve the growing volume of litigation between Muslims.

\section{Methodology}

While the examination of a religious law could be expected to follow a methodology of natural law, these terms are avoided because an impartial observer would likely categorize the Shari' ${ }^{-}$ah interpretative methodology as positivist - or perhaps in Tom Campbell's terminology, ethical positivist. ${ }^{11}$ Cognizant of this caveat, I employ comparative legal analysis as the general methodology, principally applying international law as contextually suitable and as viewed through the lens of Australian common law and the Shari ${ }^{-} a h,{ }^{12}$ using a positivist approach. ${ }^{13}$ An important caveat in this process of comparative legal analysis, however, is that there is not a shared or common understanding between the common law and Shari ${ }^{-}$ah legal traditions of the many legal concepts employed, and one thus has to be careful when drawing conclusions based on translated terminologies and concepts.

Enforcement of Shari' ah personal law obligations is not lawful in Australia and, therefore, this jurisdictional issue is not considered in any detail. Generally however, even when those in power do have the mandate to enforce the Shari'ah, many matters of "inner faith" necessarily remain nonjustifiable unless superficially judged by external trappings only. A major problem with Islamic dress generally is that it promotes a particular kind of ostentatious religiosity that is despised in Australia, and the development of the Shari' 'ah in Australia should pay particular attention to these cultural nuances.

\section{Sharī'ah Methodology}

There is general consensus that the independent Shari' ${ }^{-}$ah sources, ${ }^{14}$ the Qur'ān and the Sunnah, will be interpreted according to its most obvious meaning, ${ }^{15}$ and this is the interpretative process I have applied in this paper. For an obligation to be considered binding under Islamic law, it must either be explicitly mandated (fard) or an act explicitly prohibited (haram) in the independent sources - or, alternatively, under the dependent sources, as developed by jurists and validated over time by Muslim consensus. ${ }^{16}$ All other acts fall between these two ends of the spectrum. While these acts may be viewed variously under the Shari' ${ }^{-}$ah as meritorious or other- 
wise, adverse temporal ${ }^{17}$ legal consequences do not usually attach for their neglect. ${ }^{18}$

An alternative source of general Shari'ah law, although not binding in the first instance, is preexisting custom. ${ }^{19}$ However, only custom that is "just" is acceptable. ${ }^{20}$ Such just laws generally continued undisturbed and, in time, through debate and consensus were often recast as "Islamic norms." The variety of Islamic cultures around the world is a manifestation of the different social evolution of Muslim communities. This process is yet to occur in a systematic and formal manner in Australia, and globalization should not be allowed to subvert this wonderful and civilizing process.

Disagreement (ikhtilāf) is not prohibited except on certain fundamental matters $(u s \underline{u} l) .^{21}$ There is no question that what is universally accepted as $u s \underline{u} l$ is binding on all Muslims. Broadly speaking, $u s ̣ \bar{u} l$ are matters on which the Qur'ān or the Sunnah, the practice of the Prophet (ȘAAS), are clear or where legal provisions are based on evidence that is certain. An overarching principle in this regard is that obligations (fard) based on the independent sources (qat'i) are classified as "certain," while those obligations (wajjib) based on the dependent sources are classified as probably correct (zann). ${ }^{22}$

Diversity is actively encouraged in Islam as in perhaps no other faith or ideology. The Prophet said: "Difference of opinion is a boon to my community," 23 also that "there are as many paths to God as there are seekers after the truth," 24 and he actively encouraged a diversity of views. ${ }^{25}$

As Islam moved out of the Arabian Peninsula, there was a pressing need to develop new law. The process of developing laws for novel situations or rules for evolving situations is called ijtihad. ${ }^{26}$ However, regulating ijtihad became vital as it can be the subject of extreme individualism and consequently created the need for stable methodologies to help the crystallization of consensus. ${ }^{27}$ These rules and methodologies, now codified in the various schools of thought (maadahib), have served the Muslims well for over a millennium and should not, therefore, be discarded without extensive debate and a strong consensus.

A manifestation of contemporary acceptance of such difference (although perhaps not entirely harmonious) is the simultaneous participation of the followers of the various Islamic legal schools - mainly Sunni and Shī'ah, but also including less mainstream groups such as the Alawi ${ }^{28}$ - at the hajj or the umra (the minor pilgrimage). Another example is the coexistence of orthodoxy, the exact meaning of which changed over time and because of some heterodoxies of the time. ${ }^{29}$

Legal interpretation generally is not a straightforward process if carried out systematically, methodically, and transparently, and this is particu- 
larly so under the Shari' ${ }^{-}$ah because there has been a substantial accretion of Islamic legal material over the past 1433 years. ${ }^{30}$ Clearly, not all this law or jurisprudence is relevant today and could reasonably be bypassed, but where appropriate, however, for standing presumptions - and in this case, that all but the face and hands of a Muslim women should be covered in public, should first lawfully be rebutted, and done so in accordance with proper legal methodology. Note also that presumptions can lawfully be suspended for legal necessity, as is proposed was the case with Mernissi's parents and grandparents' generations (that being colonized created a situation of necessity in that women were unveiled through the laws and customs of the colonizers).

While the term Islamist ${ }^{31}$ is inexact, it is sometimes used synonymously with the terms Salifi or Wahhabi to describe Muslims ${ }^{32}$ who are perceived somehow as being "fundamentalist" and because they can be more vocal, their views are better heard and are thus a useful point of reference. A contemporary "Islamist view" is that Islamic jurisprudence must somehow be purified, making it free of all "extraneous influences," 33 which in cases could require ignoring precedent and the jurisprudence - and for this reason, is a view not endorsed here. In this context, some of the law-making process of the twentieth century have been described as purely "goal oriented." 34

Less instrumentally, conditions such as colonial occupation of Muslim lands arguably triggered necessity as a legal basis for abandoning Islamic traditions and values in favor of the secular, as perhaps was the case with Mernissi's analysis. If legal necessity is invoked, then such need must be argued and established separately in each jurisdiction.

With respect to women's issues, Ayesha Imam notes rightly that there is a desire on the part of men in many countries to "control women and their sexuality," 35 including through law. While not condoning this phenomenon, the trend among some Muslim men arguably has more to do with instrumental contemporary interpretative processes, and a prevailing culture of patriarchy in the West that is used to justify patriarchy elsewhere than it has to do with the principles and fundamental (ușūl) laws of Islam.

On the other hand, while some Muslim feminists have urged Muslim women in reaction to abandon the presumption "for hijab" - and while clearly understandable on an emotional level, as is argued below, such an abandonment is on the facts unnecessary in Australia. It is thus posited that Bullock's position - which reflects the broader consensus of Muslims and Islamic scholars and encapsulates a deep knowledge and understanding of Australian culture and mores and is within the scope of Australian law - is, therefore, better the presumptive position for Australia (and I explore it further below). 


\section{Definitions}

The key legal concept with respect to the covering of one's body, male or female, is that of awra, very loosely used here as an indicator of modesty but is the foundational definition in Islamic law for the determination of an appropriate lawful form of Muslim dress. Under the Sharī'ah, the awra are the parts of a male or female body that must be covered and cannot under normal circumstances be exposed - excluding a select, predefined class of persons.

The Qur'ān uses the word awra, but only in a related context. ${ }^{36}$ The Qur'ān is not prescriptive with respect to what parts of the body mandatorily need to be covered in public. The root of the verb awra denotes something that is not perfect, the human genitals or something that should be covered and thus be hidden from others' eyes. ${ }^{37}$ This general term awra is analysed in conjunction with the Qur'ānic reference to a piece of cloth called the khimar, which pre-Islamic women wore over their heads (but customarily their chests and necks were exposed), ${ }^{38}$ and, therefore, not identical with the contemporary hijab. The Qur'ān required the then newly converted Muslim women to draw this khimar over their bosoms. ${ }^{39}$ This Qur'ānic command can, thus, be read as a rule of general application in which it is mandatory for a Muslim woman to cover her bosom, a matter discussed below under "Hijab."

The term hijab, sometimes loosely translated as a headscarf (khimar) under Islamic law appears to refer to the piece of cloth that variously covers the woman's hair - as worn by European (Bosnian, Turkish, Albanian or Russian Caucuses) Muslim women in Australia, or the hair, neck and shoulders, as worn by Asian (Malays or Arab Sunnis or the dark head cover and cloak worn by some Lebanese and Iraqi Shi'tes) - but in any event, are all groups that customarily covered their bosoms separately with a blouse or dress. In this context, it is noted that Bullock is not prescriptive with respect to a style or form of "proper" hijab and is therefore accommodating of the diversity of the styles present in the Australian Muslim community.

Bullock also notes that the term veil as used in English and in the Anglophonic tradition usually refers to a transparent piece of cloth attached to a woman's hat - and which can be drawn over a woman's face for modesty and is, therefore, in practice closer in meaning to the niqab, where the fabric covers a woman's face, covering one or both eyes. ${ }^{40}$ In this paper, the term hijab is used for the headscarf, however worn, and niqab as the face veil.

If Islamic law is to be determined or altered for particular exigencies, however, say to cater for local conditions in Australia, this must occur in 
a principled and systematic manner through a recognized process of ijtihad. The use of ijtihad is not uncontentious. ${ }^{41} \mathrm{~A}$ brief synopsis of ijtihad follows: when there is an issue of uncertainty - say something novel on which the Qur'ān and or the Sunnah or Islamic law are silent or, on which consensus (and in this instance local consensus) has not yet evolved, ${ }^{42}$ and in the absence of a "just" local custom that is accepted as correct by the overwhelming majority of the local Muslims - then the dependent sources may be interrogated to help develop the law, rebutting any relevant prevailing presumptions on the issue. The key dependent source in this context of hijab or niqab in Australia is customary law, and I will now examine it.

The word custom ('urf) appears in the Qur'ān in the context of preexisting obligation but not in the meaning of binding custom, ${ }^{43}$ as in under customary international law. ${ }^{44}$ During the Prophet's mission in Medina, Medina's custom served as the backdrop to the developing Shari' ${ }^{\circ}$ ah and was recognized ${ }^{45}$ as a dependent source of law in Islam. ${ }^{46}$ That is, the early Sharī'ah, which evolved during the revelation of the Qur'ān, did not occur in a vacuum but that existing custom, and importantly, a customary system other than that of the Quraysh, ${ }^{47}$ or of Mecca, served as this preexisting foundation. Rudolph Peters explains that Imam Malik's attempts to codify and systematize the customary law of Medina ${ }^{48}$ - and in this context, Medinan custom was, and still is, used to some extent by all Muslims who emulate Arab custom as part of their faith, and importantly in this context, dress.

Some Islamic legal schools refer to the general abrogation of all preIslamic laws and customs by the Shari' ${ }^{-} a h$. In practice, however, as in Medina, abrogation was interpreted as the abrogation only of existing laws and customs that were unjust or inconsistent with the Sharīah. ${ }^{49}$ With conquest, Muslims adapted laws of the Jews, Romans, and Persians. ${ }^{50}$ In practice, the Shari' $a$ ah has coexisted with the many customary laws of conquered peoples, ${ }^{51}$ and custom has always been a practical source of law under Islam. ${ }^{52}$

There is also evidence of the accommodation of preexisting custom in other Islamized, non-Arab societies. ${ }^{53}$ It would appear to be unjust to treat Australia as an exception to this timeless process by limiting the development of Islamic law solely to adapting the customs of immigrant communities and denying Australian converts an opportunity to develop Islamic law based on their own "just" customs - fair and just Australian customs, which are in keeping with $u s \underline{u} l$, and also fruru (laws over which there is not an overwhelming consensus).

In contemporary Australia - while only a few older Orthodox Christians, nuns, and deacons wear the habit, and a few other Australians use the 
English veil at weddings and funerals - the custom of covering, on the other hand, is not entirely alien to ordinary Australians. Thus, generally other than among the so-called "loony right," it is sometimes the arrogant acts of the few Muslims that appears to raise the ire of the public, but to characterize the broader public as intolerant on this issue would not be accurate. ${ }^{54}$

\section{Interpretation of the Sharī'ah}

According to Islamic legal theory, discovery of law through ijtihad is possible, necessary, and permissible, but must among other things be accompanied by "right intent." The intent of the Qur'ān and Sunnah generally is referred to as the maqasid (the general discussion), of which is outside the scope of this paper ${ }^{55}$ - but, according to al-Jawziyyah (d. 751/1350), the maqasid includes "educating individuals, establishing justice, hindering injustice and promoting the interests of the public, ${ }^{56}$ all issues relevant in the Australian Muslim context. Legal opinions of jurists developed through ijtihad must however, be within the scope of the Qur'ān ${ }^{57}$ and the Sunnah ${ }^{58}$ and subject to Muslim consensus. While the Qur'ān is a Divine source for Muslims, it is, and always has been, accepted that interpretation is done through human minds, both male and female. ${ }^{59}$

In its words, the Qur'ān is a guide for all those perhaps paradoxically, ${ }^{60}$ who prepossess the quality of taqwa (righteousness). ${ }^{61}$ The Qur'ān describes the people of taqwa as those possessing attributes and performing acts beyond what can superficially be passed off as birr (righteousness), ${ }^{62}$ but deepens the definition in the following terms ${ }^{63}$ :

It is not righteousness that ye turn your faces toward East or West ${ }^{64}$ but it is righteousness to believe in God and the Last Day and the Angels ${ }^{65}$ and the Book and the Messengers; to spend of your substance out of love for Him for your kin for orphans for the needy for the wayfarer for those who ask and for the ransom of slaves; to be steadfast in prayer and practice regular charity; to fulfil the contracts which you have made; and to be firm and patient in pain (or suffering) and adversity and throughout all periods of panic. Such are the people of truth, the people possessing God consciousness.

It is noted that although modesty and right conduct appear implicit in the requisite criteria, the question of women's (or for that matter men's) attire does not rate a mention in this fundamental definition of what constitutes righteousness. While dress can clearly demonstrate and express the inner faith of a believer, it can also accentuate the superficial particularly when these inner matters of faith are clearly absent. This absence is particularly poignant when the aim of Islamic dress is that the wearer is rec 
ognized as a Muslim woman, ${ }^{66}$ but where poor or bigoted behavior can be detrimental to good community relsations. ${ }^{67}$

\section{The Current Australian Legal Position on the Head Cover}

There is at present no legislation in any Australian jurisdiction that mandates or proscribes religious symbols. ${ }^{68}$ The use of the face veil too is not regulated under law, except for both men and women, in some limited circumstances such as at immigration counters, banks - or recently, for purposes that require positive identification for legal matters. The New South Wales Parliament passed special laws permitting police to require a person to show his or her face in order to ascertain that the identity of the driver accords with the image on the drivers license after a Muslim woman won a case on what can loosely be described as a case of mistaken or unproven identity. The person in that case was wearing the niqab. ${ }^{69}$

The Sayed Case, which was heard in the District Court of Western Australia (WA), applied the common law on the niqab. This was a criminal law case that alleged some financial irregularities on the part of senior staff in an Islamic school. During the course of the trial, a prosecution witnesses, who had been affiliated with the school and was known to the defendant was required to testify. This witness wore the niqab.

The defense team - acting for the principal, a Muslim familiar with the issues of the niqab and hijab in the broader Australian community - argued that a witness, whose face was covered, denied the defense a fair chance of assessing the credibility of her testimony and asked the court to direct the witness to testify minus the face veil. While not suggesting that this position was tactically unreasonable, the defense stance brought (the peripheral) issue of the niqab into the spotlight, greatly politicizing an otherwise ordinary fraud case by bringing it to national and international attention. ${ }^{70}$

The witness said that wearing the niqab was her "personal preference" 71 and not a religious issue, but the niqab issue having attracted the public's interest did not abate until the judge suppressed publication of the case transcript - thus, depoliticizing the matter by taking it out of the public's attention. ${ }^{72}$ The issue of the woman's hijab was not a matter for the court.

\section{Consensus (Ijma')}

Consensus is a source of Islamic law. ${ }^{73}$ Traditionally, classical jurists have been reluctant to accept the consensus of scholars, particularly those on a state's payroll, as they are susceptible to the influence of power. ${ }^{74} \mathrm{Al}-$ Shafi' $\overline{1}$, which is the prominent school of law in Southeast Asia, "did not 
validate the consensus of,"75 and "almost rejected the consensus of scholars," 76 arguably for the same reason, but later settled on the position that the consensus of the masses was preferable. ${ }^{77}$ This view probably emerged because of the levels of government coercion and corruption in Muslim states in the past, a situation that has not changed appreciably.

For this reason, while the position of the scholars is considered the view taken in this paper the tradition of Shafi' 1 that the consensus of the Muslim masses is a better guide to what actually constitutes binding law (fard); however, but if Muslim consensus is absent, the scholars' consensus indicates, at best, that the matter is wajib. As noted above, the consensus in Australia appears to be that Muslim women regularly do not cover their hair and, therefore, arguably do not consider it mandatory (fard), but will nonetheless cover on religious or culturally significant occasions, conceding that subjectively for these women in these social situations that hijab is at least desirable. This differential behavior shows that the women are making subjective distinctions between religious and nonreligious activities.

Some Muslim practice in Australia is affected, rightly or wrongly, by a fear that the hijab will draw unwarranted attention to the person - and for these women, practice in avoiding the hijab, therefore, is not a free and informed religious choice and cannot reasonably contribute to the formation of consensus.

Notwithstanding, therefore, that Mernissi's position of supporting the abandonment of the veil reflects current Australian practice, I submit that this is not the right presumptive legal position under the Sharī'ah, or Australian common law. Further, in cases, because practice is based on a subjective albeit unfounded fear of ostracism, it is also wrong in law. On the other hand, Muslims believe that they have a guarantee from the Prophet that Muslims will not as a collective agree upon something that is wrong, ${ }^{78}$ and provides a firm legal basis for consensus formation at both local and global levels.

However, the Prophet's statement on "disagreement"79 is a clear acknowledgement that, while reasonable people may differ, it is extremely unlikely that consensus will emerge on what is manifestly wrong. I posit that the strong, well-reasoned and reasonable positions of the many independent scholars - and some such as Bullock who argue for the rethinking of the issues surrounding the hijab - must be taken into account at a time when acts based on apathy or fear can pass for consensus.

On the other hand, and cognizant of the problematic nature of these subjective determinations on issues not "manifestly wrong," the Prophet encourages those who are ignorant of the legal issues to side with the 
overwhelming majority. ${ }^{80}$ It is noted anecdotally, that there is no clear or broad general consensus among Australian Muslims on the religious necessity or otherwise of the hijab, and it is time that the various positions were examined, clarified, and crystallized into some form of consensus. The overwhelming majority of Muslims in Australia consider niqab as not mandatory, but on the other hand do not prohibit its use. Anecdotally, niqab appears to be practiced at various times by many Muslim converts, arguably to help them integrate into a largely immigrant community - which is also in some cases unwelcoming, once again not generally so, but because of the loud voices of an obnoxious few.

\section{Hijab in Australian Society}

The question of hijab, and the precise extent and style of cover usually is settled locally in many Muslim-majority states. However, in Australia, where there are immigrants from many different Muslim states, many Muslim women regularly do not wear the hijab. In support of those who do not wear hijab, we can look to Mernissi, who documents how their mothers and grandmothers fought against the veil. ${ }^{81}$

While Muslims have been present on the Australian continent for nearly four hundred years, the first Makassars have left few traces of their seventeenth-to-nineteenth-century life and presence on the Australian continent. ${ }^{82}$ Later immigrants such as the Malay pearl divers of the early 1800 s too have left few traces of their Islam and their fourth and fifth generation decedents almost overwhelmingly do not identify themselves as Muslims. ${ }^{83}$ Further, the Afghan cameleers of the mid-1800s who helped "open up" the continent's desert interior to colonization too were mainly men who married non-Muslim women who did not adopt the hijab - and over time, while some small pockets of Islamic identity remain, the vast majority of their descendants have assimilated. ${ }^{84}$

This is probably because these early Muslim immigrants lived in much less tolerant times - including between white settlement and the end of World War II, and under the White Australia policy when colored migration was proscribed. As a result perhaps of the pressure to assimilate into a strongly Anglophonic culture, an Australian version of hijab has not emerged.

The strongly assimilationist times were followed by a period of increasing tolerance and acceptance of people both of color and of non-European cultural backgrounds - including many Muslims, Buddhists, and Hindus. For Muslims, the practice of wearing hijab or niqab was greatly facilitated by the openness of this period. The events of September 11 2001, however, 
reversed some of the tolerant attitudes, a process greatly aided and encouraged by jingoistic politicians.

Notwithstanding the events of September 11, the clock has not entirely rolled back to the attitudes of White Australia, and there is still a much greater general understanding of the Muslim world. The media such as the Australian Broadcasting Corporation, a public broadcaster, has done much to increase the public's understanding of Islam and Muslims through its radio, television, and web programs.

Nonetheless, Islam continues to remain largely a faith of first generation immigrants and their families, and it is yet to be seen whether these newer immigrant groups will use the more liberal religious atmosphere and policies such as multiculturalism to evolve more sustainable cultural forms of Australian Islam, steps not dissimilar to those recommended by immigrant Muslims and their children in other Western societies. ${ }^{85}$

Anecdotally, and based on unofficial and fairly rough polls, which were not statistically based or constructed and carried out at Islamic centers in Sydney and Canberra, indicated that about 15 percent of women wore hijab regularly. ${ }^{86}$ The number wearing niqab is well below 1 percent of Muslim women. ${ }^{87}$ By the Shafi'ite criterion, as the practice of Muslim women is the better indication of consensus on hijab, then Australian Muslims do not consider either hijab or niqab binding. However, notwithstanding the clear views of people like Mernissi to the contrary, few Muslim men or women openly challenge the notion that many Muslim scholars consider hijab mandatory. ${ }^{88}$

\section{“Islamic Dress” Under Islamic law}

The starting point with respect to a Sharí ${ }^{-}$ah analysis must be a textual analysis of the relevant Qur'ānic verses. This is followed by the analysis of dress in the Sunnah, examined in the contemporary Australian customary context outlined above.

The word hijab occurs seven times in the Qur'ān. Mernissi notes that the word often is used in a negative context, as something that prevents one perceiving good, as in the hijab of self-aggrandizement preventing humanity from perceiving that which is good, or a "screen" preventing the wicked from seeing God on the Day of Judgment. ${ }^{89}$ Most of the Qur'ānic references to hijab, however, do not really address the question at hand. Only the verses, directly or substantially relevant to "dress" are examined below, whether or not they contain the word hijab. 


\section{What is "Modesty"? The Concept of Awra}

As noted, the fundamental Qur'ānic concept with respect to Islamic dress is that of awra..$^{90}$ There is no real English equivalent of the Arabic term awra. While modesty is a subjective notion, as a Qur'ānic legal concept, it must also have an objective element. The objective test is not prescribed fully in the independent sources and leaves some discretion for local social conditions. ${ }^{91}$ Thus, what is Islamically modest can be gleaned from the Sunnah, and the dependent sources, ${ }^{92}$ through judicial construction. There are a number of local customary forms of dress and even local consensus in cases, but there is no global consensus except of what must be covered up during religious rites such as the ritual prayer and pilgrimage.

What actually constitutes modesty has for centuries been interpreted and constructed within the framework of the local contemporary cultural context, together with the Prophetic statement to cover "all except the face and hands" discussed below. ${ }^{93}$ As mentioned, this is a very particular hadith, relating to the Prophet's sister-in-law and is discussed below. However, all schools of thought, which incidentally like the Shafi' 1 school are usually referred to by the names of their eponyms, (both Sunni and Shi'sah ) have variously adapted this hadith (see below on the discussion on the exposure of the feet, or the case of slave Muslim women).

For an objective understanding of what Muslims might consider constitutes "modest dress" in Australia, a useful indicator would perhaps be what visitors and guests wear to open days at a mosque. Most mosques require (and advertise that) "modest" dress should be worn, and ordinary Australians in various forms of attire do take these opportunities and are welcomed to familiarize themselves with these places of worship. No one is reasonably expected to wear hijab; they are allowed to visit the mosques when modestly attired. While it is difficult to describe with any degree of precision as to what is the range of clothes worn on these visits, what is very clear however is that the Muslim community, by overwhelming consensus, considers that clothing other than the hijab for women can constitute modest attire. It is noted, however, that such clothing, if worn by Muslim women, while modest is clearly not distinctively Muslim.

\section{Men's Awra}

The Qur'ān does not specifically provide for a man's awra. ${ }^{94}$ The key legal yardstick here then is the issue of what parts of the body must be covered for ritual rites, although given that a person in this position is deemed to be in God's presence, this level of covering might be considered an upper limit of what must be ordinarily mandated to be covered. It appears settled 
through consensus that a man's awra is the area between the navel and the knees, both inclusive, and the material that is used for this purpose should not be of silk or gold, the wearing of both which are prohibited to Muslim men. ${ }^{95}$ There are, however, no temporal Sharī'ah legal sanctions prescribed in the Qur'ān and Sunnah against Muslim men who breach these limits.

\section{Women's Awra}

Similarly the Qur'ān does not fully provide for the woman's awra, ${ }^{96}$ and again the Sunnah must be interrogated in this respect. The extent of the awra for women for everyday matters does not appear to have universal consensus, nor is the matter considered $u s ̦ \bar{u} l$. While Bukhari, the main collection of Sunni hadith, dedicates several pages to the issue of dress, it does not prescribe the issue of hijab or niqab in any level of detail. ${ }^{97}$ Two other Sunni collections of hadith by Muslim ${ }^{98}$ and Malik ${ }^{99}$ are even sparser for both men and women in the context of the appropriate attire for ritual prayer. ${ }^{100}$ Malik refers to questions posed by women with respect to dress during prayer. ${ }^{101}$ Perhaps, Muslims at the time of the Prophet were not preoccupied with matters of women's dress and were possibly concerned with much more pressing and important issues of the day. ${ }^{102}$

The Qur'ân however, does prescribe the proper use of the khimar. Again, while not comprehensive, the Qur'ān does provide for this one element of a free Muslim woman's dress, and prescribes that her bosom must be covered. ${ }^{103}$ This Qur'ānic requirement is further particularized by the hadith in which the Prophet advised Asma, his wife's sister to cover all but her face and hands, presumably when Asma went out in public. Although it must be noted that the marriage by the Prophet to Asma would have been prohibited under the Qur'ān, ${ }^{104}$ and less rigorous rules of dress would have applied as between the Prophet and Asma, and thus one would presume that a law of general application could not solely be based upon this hadith. ${ }^{105}$

As a touchstone, however, and in contradistinction with general matters of dress, there is clear universal consensus surrounding the mandatory aspects of the Muslim covenant $(u s \underline{u} l)$ such as belief in the one God, prayer, fasting, the tithe, and the pilgrimage. There is little, if any, doubt on the existence of consensus on these matters, including on the dress requirements for ritual worship. Thus, as with men, what must be covered can on the facts be gleaned from the dress required for worship.

For convenience, in this analysis, the areas of women's dress is considered under the two headings, the khimar (the head cover) and the jilbab (broadly speaking, the body cover or cloak). This separation is arguably 
permissible because a person's head, face, and body are treated differently by the Qur'ān for theological purposes - for example, for ritual ablutions. ${ }^{106}$ Note however, that save for legal necessity, the dress for prayer for both free and slave Muslim women is the same, and practical concessions for other times are perhaps to enable the slave woman to perform her work less encumbered.

It is now accepted by Muslim states under international law, ${ }^{107}$ that slavery is prohibited, although perhaps not so in practice. ${ }^{108}$ However, the existence in legal principle of a distinction between free and slave establishes that the clothing prescribed for prayer is not identical to clothing prescribed for general purposes and that although concessions were granted to slaves generally, given their precarious position in society, ${ }^{109}$ the same general concessions may not be available to free women, even if they are in the work force.

\section{Hijab in Islamic Law}

The Qur'ān requires that "believing men ... should lower their gaze and guard their modesty." 110 For believing females (the "hijab verse"), the Qur'ān states:

that they should lower their gaze and guard their modesty; that they should not display their beauty and ornaments except what (must ordinarily) appear thereof; that they should draw their veils [khumurihinna] over their bosoms and not display their beauty ... and that they should not strike their feet in order to draw attention to their hidden ornaments. And $\mathrm{O}$ ye Believers! turn ye all together towards God that ye may attain Bliss. ${ }^{111}$

Dress restrictions for both men and women generally appear secondary as compared with the primary concern of protecting modesty. Further, the final sentence in the hijab verse is a promise of reward for good-faith compliance, not a threat of punishment for breach.

Here, the resulting twofold question is:

1. What does "modesty" mean? And in this context, what does a man or woman have to cover up to be considered physically modest, conceding that a person can be dressed appropriately and yet draw attention in a way that is unbecoming or immodest?

2. What is the jurisdiction and scope provided by the Shar' 'a a competent authority in permitting them socially to encourage a dress code, which is likely to be accepted as reasonable and is considered just by local Muslim community consensus. The examination of the jurisdictional aspect of the second question is not necessary for the purposes of this paper as Islamic law is not 
operative in Australia other than where an individual voluntarily submits to its jurisdiction. Australian Muslim leaders have no legal authority to enforce dress standards - and, therefore, I do not consider this aspect any further. The scope of the law in prescribing the extent of the cover required is discussed below.

The autonomy and unfettered individual choice with respect to choosing and the degree to which one observes one's faith both in Australia and under Islamic law is settled. ${ }^{112}$ The Qur'ānic onus on the individual Muslim is to protect his or her own modesty - whatever this might mean in a subjective sense by guarding his or her eyes and by dressing modestly. Incidentally, there is nothing in the words of the Qur'ānic provision that suggests that Muslims must enforce such a "covering up" of an "offending" party.

However, some Muslim majority societies do enforce cover, such as the niqab in Saudi Arabia. The religious basis for enforcing women's dress standards does not come from the Prophet's practice ${ }^{113}$ but arguably derives from a particularized interpretation of a very general Qur'ānic verse. ${ }^{114}$ According to the Qur'ān, notwithstanding this enforcement in places of women's dress code, whether or not the other party is fully and modestly clothed is not a relevant consideration. The command to both Muslim men and women is to look down - that is, away from what is unlawful - and this obligation holds in all circumstances; the hijab verse does not import authority to order change in the offending party. In fact, an obligation to cast down their eyes makes enforcement by the fact questionable as it requires disobedience to this Qur'ānic injunction. In a normative sense, a Muslim should first obey the law pertaining to him or herself in preference to saving others, particularly at the risk of disobedience or hypocrisy.

An addition to the "twofolded question" above then is what do the Shar'̄ah-dependent sources recommend as a Muslim woman's general attire, which a Muslim may subjectively formulate in order to foster her own belief and practice? The hijab verse requires women to cover their bosoms - and having covered their breasts, women should not then nullify this good act by otherwise drawing unwarranted attention. This is an added bit of advice to Muslim women, not to give less disciplined men or those not bound by the Qur'ānic injunction to cast down their eyes, a pretext or defense for their own transgressions whether physical or otherwise. The vernacular for this kind of defense in Australia (and no doubt many other jurisdictions) is that "she was asking for it." Clearly such a defense is neither admissible under the Sharī'ah criminal law, ${ }^{115}$ nor under Australian law.

The hijab verse, nonetheless, takes cognizance that such attention seeking or seduction can in some cases perhaps cause unlawful desires in 
others. The acting out of some of these desires can in some instances be a breach of the Sharī'ah criminal law, but if consensual, generally, is not now in breach of Australian criminal law. This verse clearly prescribes both the letter and the spirit of the provision or its maqașid, which is the protection of the modesty whatever this might mean in a particular community - depending upon the degree of application of the Qur'ānic concession for "what might (customarily) appear ordinarily thereof" in that locality, and is discussed below.

The absence of temporal sanctions for breach of awra provisions (or for a lack of modesty) is not to underplay the importance of modesty as a religious issue. The ritual prayer, a crucial matter for Muslims, carries no temporal sanction for its neglect, but this fact alone does not diminish its import. Similarly saying that a woman's manner of clothing is her own business is not to say that for believing woman (and men) that the absence of temporal sanction alone is a bar to the practice of what they may individually and subjectively believe is mandatory or which pleases their creator. Katherine Bullock, an Australian Muslim woman, negotiates these tensions in a principled and precise manner and a neglect of such awareness trivializes this important debate.

Anecdotally, however, some Australian Muslim women, who do not wear the hijab, still appear to consider the hijab as religiously necessary, perhaps because it was customary in their home countries or have anecdotally heard that this is an important element of a Muslim woman's attire. At any rate, the stereotypical Muslim woman as shown in the Australian media is inevitably covered, although this is arguably for greater visual effect rather than an understanding of the underlying Shari' ${ }^{\top}$ ah laws. ${ }^{116}$ Some Muslim women, perhaps those who feel the obligation to do this, also sometimes take up or revive the practice of hijab as they realize that Australian society generally is more accommodating than the few loud Islamophobic voices, or even their own internal but often unsubstantiated or exaggerated fears.

On the other hand, globalization has had a homogenizing effect in some Muslim communities, particularly with respect to limiting or restricting women's autonomy. In an example, described by Imam

The Bashir regime in the Sudan, for instance, attempted to impose the Iranian chador on Sudanese women in the early 1990s..$^{117}$

This effort was not successful in the Sudan. That is, an effort by some Muslims to create "instant custom," as in international law, ${ }^{118}$ was unsuccessful in that instance. Efforts by men and women to impose non-indigenous religio-cultural norms, particularly custom, on which there is not a 
broad consensus, has not appeared to have succeeded to date. In a similar example, the United States and its allies have not been able to discourage the majority of Afghan women from wearing the blue burkas.

While the use by women of the head cover decreased significantly in colonial times - particularly in the urban areas of colonized Muslim States ${ }^{119}$ - the process of decolonization over the last fifty years or has resulted in some women reveiling, ${ }^{120}$ and might perhaps result in the evolution of new norms. If this argument is correct, it indicates that the better view is that - where there is not an explicitly mandated form for women's clothing other than for Qur'ānic requirements and a broad consensus that both men and women should dress modestly - that rules and consensus around these matters are best allowed to evolve separately and independently in each separate locality.

\section{Khimar}

The Qur'ān requires believing women to "draw their veils over their bosoms," 121 - their chests and the upper parts of the body, which were not always covered even by free Muslim women in the early days of Islam. Note that the word veil has slightly different connotations in English. ${ }^{122}$ The original word used in the Qur'ān is khimar (a piece of cloth worn over a woman's head).

While one could argue that the khimar already covered a free, preIslamic woman's hair - although the extent of cover was clearly not as strict as is the contemporary expression of the hijab, (that is, according to some schools, that no more than three hairs may be exposed). We also do not know whether the pre-Islamic custom required women to cover their hair at night or in public generally - that is, when not exposed to the hot Arabian sun (that the khimar was worn for purely functional reasons, as did men of the day who also covered their head necks and shoulders, a practice continued to this day, but is not religiously significant, although on the other hand this custom is practiced by non-Arab Muslim men particularly during ritual prayers). However, the pre-Islamic society considered exposing women's breasts, nude circumambulation of the Kab'ah, and burying infant daughters as acceptable - and this could not reasonably be perceived as a community that covered their hair in public, as do Muslim women in hijab for reasons of modesty or propriety.

Nonetheless, custom - and notwithstanding that the original reasons for its adoption was functional rather than for modesty - can subsequently, as with men in the Shafi' 1 school covering their heads during prayer, become binding, subject to the proviso that such custom is "just." Hijab or 
any other custom for that matter, if it regularly results in Muslim women's molestation, would be difficult to characterize as just. Adverse reaction by Australians to Muslim women in hijab, while not unknown, is far from regular or common. Even in these instances, it would be difficult to establish that hijab was the sole reason for the adverse encounter. ${ }^{123}$ Thus, a customary religious requirement for a Muslim to wear a khimar is unlikely to be considered unjust by the majority of contemporary Australian Muslims.

However, given the unique status under the Shari' ah of the Qur'an as "God's literal word," it is noted that in Islam that one must constantly "recalibrate" Sharī'ah laws with respect to this fixed point if interpreters are true to their assertions of fidelity to the text as God's word. Importantly in this context, according to Kecia Ali, the text is also protective of women's rights, ${ }^{124}$ which she notes, includes "many matters of gender and sex," $125 \mathrm{a}$ view that I strongly endorse.

Such periodic reevaluation of norms and laws will help to rectify historical anomalies, which have resulted from external pressures - for example, colonialism. As documented by, but not argued as such by Mernissi, political conditions during the colonial era had necessitated her predecessors to abandon the veil - and in order to do so, they had to fight vigorously against the weight of Islamic jurisprudence, and then they established a precedent to achieve this outcome.

The alleviation of repressive political pressures or the practical absence of coercive pressures in communities such as in Australia must then trigger the re-interpretation process of the primary sources to allow for these more liberal (as they once accommodated the more repressive) circumstances by following the most practical interpretation that fits the Qur'ān. How this must be achieved is not contentious in principle, which is that the reformulation of the law must be done with taqwa - or to put it in contemporary parlance, in a principled manner. This process can be frustrated through instrumental or goal-oriented development, which Roberto Totoli notes is characteristic of the twentieth century. ${ }^{126}$

\section{Local Dress Customs}

Recall that Qur'ān 24:31 is qualified by the phrase "except what (must ordinarily) appear thereof (illa ma zahara minha),"127 which Khaled Abou el-Fadl reasonably notes "is an indication that the laws of modesty might partially depend upon customary practices within a society." 128 Mohammad Asad notes that the broad wording of "what must ordinarily appear thereof" is much wider and its deliberate vagueness permits time bound changes that are necessary. ${ }^{129}$ In this context, the Qur'ān warns against increasingly narrow constructions that, in attempting to "create certainty,"which collat- 
erally can curtail flexibility and unnecessarily reduce their scope. ${ }^{130}$ While the Qur'ânic concession is potentially as broad as is reasonably necessary in a particular society, I will in this context focus solely on the hair and face.

As with many Qur'ānic verses, however, this verse is stated at a high level of generality, and the Shari' ah methodology is to look to the Sunnah for its practical application. The oft-repeated hadith in this respect states that women should only show their face and hands. ${ }^{131}$ This view is, however, neither unanimous nor conclusive. ${ }^{132}$ For example, some schools hold that women can expose their feet even in prayer, while others mandate covering. 133

Over time, local consensus on what is appropriate with respect to women's clothing arguably has evolved separately in different Muslim communities, although there are also clearly areas of broad agreement. Notwithstanding the position of the jurists who advocate head cover, one can however assert with some certainty that there is not a uniform Muslim consensus on head or face cover.

Asad cites the respected jurist Zamakshari (d. 1144) - who in his commentary of Qur'ān 24:31 on "what might ordinarily appear," notes that women must show their faces in litigation in court, for purposes of marriage or are permitted to expose their feet in the streets, particularly if they could not afford footwear. ${ }^{134}$ As mentioned, exposing even free women's feet during ritual prayer is also permissible in some schools ${ }^{135}$ and shows that the jurists did not take the Prophet's words to Asma literally and as definitive, but only as indicative of what might be covered. Further, el-Fadl cites the hadith literature to show that Muslim slave women do not have to cover their face, hair, or arms and gives an insight into the thinking of jurists from a bygone period. ${ }^{136}$

In this context, Imam has documented and described the everyday manifestation of this observation of "what may ordinarily appear" in the variety of Muslim women's clothing used by women:

Muslim women's dress codes are often misleadingly referred to generically as veiling or hijab. This obscures the historical changes in modes of dress and cultural contexts - and thus the fact that people may be talking of quite different modes of dressing when the refer to increased veiling or women's hijab. The black lose cloak covering head to ankles known as the chador in Iran is not the same as the loose swathe of sometimes diaphanous cloth draped around the body called the tobe in the Sudan. Both are unlike the headscarf and maiyafi (cloth covering head and shoulders) of 'modest' women in Nigeria. Nor are any of these identical to with the headscarf sometimes worn with jeans that is acceptable in South Africa. ${ }^{137}$ 
This variety is also some evidence that the manner in which Muslim women are covered is not universally agreed upon. These formulations cited require the cover of the hair but not face or shoulders - and further, the issue of whether covering feet, arms, and ankles is required is also not addressed. What appears from the jurisprudence, however, is that hijab formulation is not time bound and should continue to remain vague, nonjustifiable, and not enforceable.

\section{Australian Dress Customs}

In an Australian cultural context of what the phrase "ordinarily appears" might mean, consider the following. Australians generally are quite relaxed about clothing and the two ends of the cover spectrum; on a warm sunny day, expect a range of people dressed from "very scantily clad" or even nudists at one end of the spectrum to nuns dressed in full habit at the other. Both extremes are unusual, and the norm, whatever that might mean for both men and women generally appears to involve covering the area between the shoulders and knees with fuller cover in the colder seasons and climes.

The better characterization, however, of what "normally appears to be in Australia is not so much about the degree of cover, but that Australians value personal autonomy and individual choice. That is, the better yardstick is that Australians would like to be left alone to decide what is best for themselves. In other words, an Australian cultural take of "what must ordinarily appear" is to let Muslim women decide for themselves.

While some Muslims (both men and women) advocate the hijab, and in some cases even the niqab - in Australia, this is usually done in a manner that is attempting to persuade. Coercion should not be permitted. On the point of religious coercion, for children born and raised as Muslims by their parents - a substantive parental right in international law, ${ }^{138}$ recognized in Australia, but arguably not so under the Shari'ah, which may culturally include dressing in a particular way might on one view be problematic. ${ }^{139}$

On the other hand, social pressure to assimilate can in cases appear to cause great stress in younger children and young adults, ${ }^{140}$ and Mernissi's view provides a path that more closely reflects the cultural mores and ethos of Australians is convenient and, therefore, a simpler and a more attractive option particularly to those without a strong conviction that the hijab is necessary.

However, the real question is: what is the better more principled position for Australian conditions? This question it is argued is best answered by seeking a position that is legally correct under the Sharī'ah, ${ }^{141}$ excludes 
the effects of the historical application of legal necessity, ${ }^{142}$ allows Muslim women who elect to do so to be distinctly recognizable, and is respectful of Australian social and cultural norms - while being within the scope of the primary sources of Islamic law.

\section{Jilbab}

The jilbab is a woman's outer wrapping garment or a coat and takes many different local forms. It envelops the body, but covering the head is not mentioned. ${ }^{143}$ The abaya of Saudi Arabia is a woolen cloak ${ }^{144}$ and derives from the root word, which stands for "something that covers something else" (in this case, the body with cloth), and is in Saudi Arabia customarily worn with a niqab (literally a piece of cloth with an opening or hole for the eyes ${ }^{145}$ ). According to Lane and in this context, synonyms of the word jilbab are izar (a sheet that covers all but a hand) and mulaha (a flat black sheet). ${ }^{146}$ The Qur'ān recommends that Muslim women wear an outer garment when they go out:

O Prophet! tell thy wives and daughters and the believing women that they should cast their outer garments over their persons (when abroad): that is most convenient that they should be known (as such) and not molested: and God is Oft-Forgiving Most Merciful. ${ }^{147}$

For ease of analysis, the provision is considered by examining its elements. The provision states that women should be known as Muslims and, therefore, bound by a certain moral and ethical code, and to bullies, that they must desist.

El-Fadl states that this verse had very particular circumstances with respect to young men harassing women who went out at night to relive themselves (in the desert). ${ }^{148}$ Dress alone, however, can be an unreliable indicator to make any useful judgment about the wearer - other than as the Qur'ān indicates, making it convenient for Muslims wearing the jilbab to be recognized in a society in which the women did not customarily wear a cloak. ${ }^{149}$ The word convenient ${ }^{150}$ clearly does not import compulsion, ${ }^{151}$ but notwithstanding this, identity is an important issue particularly for a religious minority. Generally, however, most Australian women do not customarily wear a cloak, other than in winter or as a special evening dress. Based on this criterion, Christian nuns in habit are for likely to be "recognized" as Muslims. This is, however, not the nuns' intention. Sikhs too have been mistaken as Muslims and, thus, unambiguous recognition arguably is desirable and is often symbolically important. On the other hand, women wearing the hijab (alone) are recognizable as Muslims. 
The second element of the above Qur'ānic verse is that the reason for prescribing the outer garment is so that Muslim women will not be molested.

Mernissi's view is that the jilbab was prescribed to distinguish free women from slaves, because of the harassment and molestation of the latter that was present in Medina in the early period of Islam in that city. ${ }^{152}$ The fact that women generally can be attacked, sexually harassed, or molested in Australia is not in contention. Absence of targeted harassment or threat of molestation in a locality or the existence of general legal measures to prevent molestation could on the facts negate this element. What constitutes "molestation" is not defined, and thus, a reasonable but ordinary meaning should apply. Even absent positive law in most Australian jurisdictions prohibiting religious vilification, Muslim women do not generally fear molestation because of their faith. The absence of religiously based molestation of Muslim women means that the second requisite Qur'ānic legal element is generally absent in Australia. On this reasoning, an outer garment, therefore, should not be necessary.

The converse question is whether if "Muslim dress" was the primary reason for molestation of Muslim women, then whether it is then possible to abandon the dress, if that would prevent molestation? Harassment (and molestation) of Muslim women in veil are sometimes perpetrated by a vocal minority, ${ }^{153}$ who are arguably reacting to the hijab or niqab or the behavior of the women rather than on religion alone - although generally, the issues are inextricably linked.

What must develop in Australia, therefore, is a form of dress that identifies Muslim women - so that or even as Muslims, they will not specifically be targeted. In contemporary Australia, unlike in some Muslim majority states where poorer non-Muslims are harassed or discriminated against, ${ }^{154}$ laws of general application protect everyone. Thus, in cases where the hijab or the jilbab are the reasons for the harassment of women, the two elements of the Qur'ānic verse appear to negate each other, which is clearly counterproductive.

The Shari' ah in Australia, as indeed elsewhere, must evolve in a manner so that the two elements of the Qur'ānic provision in question operate in harmony. The broader policy question for Muslims with respect to this Qur'ānic verse is whether jibab is a convenient end in itself or a mere suggestion vis-à-vis protection - an end that in contemporary Australian circumstances can be achieved through the operation of general laws preventing discrimination of all people rather than just Muslim women alone, and better fits in with the broader message of the Prophet, which is as a mercy, among other things, to all of humanity. 
Anecdotally, the view among a significant minority of practicing Australian Muslim women appears to be that the head cover is desirable but perhaps not mandatory, although the take-up rate in Australia is possibly much lower than the figure of 40 percent cited by Bullock for women in Cairo. ${ }^{155}$ While some women may wear the hijab for purely cultural reasons, at least some of these women can be presumed to consider it mandatory. ${ }^{156}$

\section{Conclusion on Hijab}

A minority of Muslim women in Australia wear the hijab on a regular basis. Therefore, Mernissi's position, that the veil should be abandoned in modern society, is both convenient and appealing in Australia for a large number of Muslim women. It must, however, be noted that she is a Moroccan scholar basing her work in that jurisdiction's historical and social contexts, which are significantly different to those generally prevailing in Australia. Mernissi's experience possibly reflects the practical experience of Muslim immigrants, who come from Muslim majority nations. Knowledge or practice of Islam is not a criterion for immigration to Australia, and most immigrants have educational or vocational skills that will primarily promote economic and social integration - and as a broad generalization, for whom Mernissi's views appear to strike a chord. Mernissi's views, that precludes the vision of a distinctively Australian Muslim community, also appears to fit in better with longer term policies of conservative Australian governments that all immigrants should assimilate into the "Australian way of life," an evolving and fluid concept.

Notwithstanding the deference by some in Australia to Mernissi's works, and with no disrespect intended, there are few if any reasonable grounds for such deference. Convenience of abandoning the hijab is likely to be the key motivating factor. Combating patriarchy in Muslim states arguably underlies Mernissi's position on the hijab. On the other hand, paternalism is not likely to suffer greatly if Australian Muslim women doff their hijabs.

On the other hand, I favor Bullocks's position, which advocates hijab for Muslim women, as a principled position, and as opposed to the more cynical assimilationist policies of the government of the day. It better suits our society, values, community, and history - and importantly, it is in accordance with Islamic scholarship. Hijab is also a powerful symbol and if accompanied with good positive behavior can promote better intercultural and interfaith relations. These are, however, contested notions that are open to discussion, and such debate would be a positive outcome. 


\section{Niqab in Islamic Law}

While some jurists of the past have argued that the niqab is mandatory, the examination of their individual views is outside the scope of this paper that subscribes to the Shafi'ite view on consensus. ${ }^{157}$ At present, there is a clear global consensus among Muslims that niqab is not a mandatory religious requirement, except perhaps in societies and localities such as Saudi Arabia where the wearing of niqab is enforced. However, women are required to uncover their faces during the circumambulation of the Ka'bah. ${ }^{158}$ It appears inconceivable that one fundamental duty of Islam, here the pilgrimage, would require the breach of another fundamental ( $u s \underline{u} l)$ practice. Few, if any, Australian Muslims publicly claim that the niqab is mandatory. The niqab, as discussed above and demonstrated by the witness in the Sayed Case, is seen as a cultural and not a religious practice and, therefore, can be accommodated under Australia's multicultural policy, a program that has bipartisan support in the Federal Parliament.

Nonetheless, as a matter of both Sharī'ah and Australian law, the covering of one's face in some instances is religiously permissible. Bukhari narrates that the Prophet covered his face and head (at-taqannu'), making this permissible. ${ }^{159}$ Niqab, is often characterized by its proponents as mustahab (as a good act that is recommended). ${ }^{160}$

The Australian legal position with respect to the niqab was applied in the Sayed Case. ${ }^{161}$ The common law position in Australia is that hijab is permitted, as generally is niqab, except in some particular limited instances such as while providing testimony - but where cultural mores will be accommodated within the bounds of what is "just." Justice Deane, the presiding judge, stated that this decision was, however, not to be treated as a precedent possibly because the District Court is a lower court in the Australian court hierarchy, thus leaving the task of setting a precedent to a higher court.

From what has appeared in public so far, Justice Dean's decision appears identical in all key respects to that of Zamakshari. ${ }^{162}$ While not suggesting that Justice Deane was familiar with Zamakshari's work, it is clear that reasonable and fair people will reach similar decisions, as is the case here. It is a fair and wise decision, which while clearly contemporary also sits so comfortably with the jurists of the past. A systematic study of this contemporary decision would help Muslims to draw together and help crystallize a general view on the niqab around this now revived position of Zamakshari as this is now, broadly speaking, part of the common law of Australia. 


\section{Islam in Contemporary Australia}

According to Amina Wadud, "at the level of the average [American] Muslim man or woman . . . Islam is whatever they have inherited, culturally and ethnically." 163 Anecdotally, this is also the case with many Australian Muslims. Part of this inheritance is arguably a culture of violence and misogyny. Violence against women ${ }^{164}$ and misogyny are both present in the broader Australian community, ${ }^{165}$ making Muslims indistinguishable from the mainstream in this unfortunate regard. Muslims may also be isolated by language and cultural barriers that will on the facts be compounded by the niqab, but perhaps less so by the hijab. For Muslims born and raised in Australia, if the hijab or the niqab are freely chosen, sometimes causing some difficulties with non-Muslim family members, but otherwise it should not prove isolating.

There are great efforts in Australia - through law, education, and social sensitization - to help eradicate patriarchy and the unequal or iniquitous treatment of women based on their gender alone. Patriarchy is a terrible blot on a country otherwise greatly focused on issues of human rights and dignity. The Australian Muslim community too would no doubt greatly benefit Muslim women and men, as well as the border community, not to lag behind on this score - particularly given the wonderful example of gentleness and kindness shown to both women and men by the Prophet of Islam. A decrease in the general level of violence in Muslim families will improve the quality of life for its women and children. Further, decently behaved hijab wearers will improve the visibility of the Muslim community and the esteem that it is held in the eyes of the broader community.

As mentioned, Mernissi's work on the veil and women's issues, ${ }^{166}$ are well regarded in Australia. On the other hand, Mernissi's views are not in keeping with the evolving position of hijab in Australia and this area of the world and its nearest Asian Muslim neighbors, where many young women appear to be taking up the hijab for religious reasons, as an assertion of identity or in solidarity with Muslims. Mernissi's position supporting the abandonment of the veil for Muslim women is also, as discussed, at odds with Australian common law and, therefore - while not suggesting that this is an Islamic criterion - is unnecessarily restrictive as a starting point to help develop a sustainable, informed, and genuine consensus position in Australia. Mernissi's work - while advocating justice for women, a central issue for our times - nonetheless does not represent the diversity of Muslim cultures that are present in Australia.

Bullock, however, notes that the uncritical use of Mernissi's work as authoritative is problematic. ${ }^{167}$ It is posited that Bullock's views are rea- 
sonable because in addition to the undesirability in principle of uncritically accepting any proposition - in this instance, Mernissi's work, which is based on the study of a society whose history and culture are significantly different and, therefore, should not by default be considered applicable to Australia unless her conclusions are explicitly shown to be otherwise.

The two scholars' analyses result in very different conclusions on at least one aspect of the use of the veil - Mernissi, considering the veil oppressive, while Bullock does not support this broad overarching generalisation. ${ }^{168}$ Bullock's position is clearly supportive of women wearing the hijab and cites with approval John A. Williams' statement that "[the hi$j a b$ ] conforms more to the religious law of Islam than any other available dress." 169 Bullock considers the hijab as an expression of Islamic identity importing an element of religious obligation. While Bullock appears to be in no doubt that hijab is normative under the Sharī'ah, she is not prescriptive or making a call for enforcement. It is reiterated, that as an Australian, Bullock is much more familiar than is Mernissi with the Australian social, historical, and cultural context. In addition, her position also sits much closer to the Australian common law position, and is not defensive or reactive.

For these reasons, I posit that Bullock's is the better presumptive position for Australia, and I call on Muslim lawyers to positively engage with the Australian judiciary on the notion that Bullock's position on head cover would serve as a useful orthodox starting position to help the debate and the process of the development of a legal position regarding the hijab and the niqab in Australia under both Australian law and local Islamic custom - thus, helping the crystallization of an Australian Islamic position, and one that is not antithetical to the views held by Muslims outside Australia.

My plea is that Muslim and non-Muslims interested in this issue is not to confine their thinking to works such as Mernissi's, excellent as they appear from a purely Western secular perspective, but also to take a broader survey of the literature. A wider range of sources will help to develop an authentically Muslim position - in keeping with the jurisprudence and the global Muslim community and allowing Muslims to be recognizably Muslim in the best possible way. For the reasons discussed, Bullocks work should be considered mandatory reading for those in the law interested in the principled development of both Islamic custom and the Australian common law with respect to Muslim dress.

\section{Conclusion}

It is related in the Sunnah, "eat what you wish and wear what you wish if you can avoid two things, extravagance and conceit." 170 This display 
of conceit referred to certain forms of dress, and was addressed to men. For women, the issue is to not dress in a manner that is seductive, but the advice against conceit and arrogance is also apt. It is unclear as to what is the "true" position with respect to the hijab in Australia due to the absence of reliable statistical information, but it is clear that there is no general or broad consensus.

If defeating patriarchy is within the scope of the Shari' $a$ ah - as is persuasively argued by Ali, Bakhtiar, Bullock, el-Fadl, Mernissi, and many others - it is a reasonable view given the primary importance of the fundamental notion of justice in the Qur'ān, and then patriarchy must be expunged from Muslim society but done so in a positive and concerted way that is Islamically "right."

The Qur'ân describes the Muslim Ummah as the mid-most community (one that avoids the extremes) because it is upright and equitable. ${ }^{171}$ Surely, the Muslim community, and particularly its legal fraternity, can formulate a Sharī'ah-compliant form of awra for Australian conditions that is legally methodologically faithful to the sources, its rich jurisprudence and to the broader notions of justice, equity, and human dignity. A range of voices and respectful debate will help this process of the crystallization of the consensus on this issue.

At a general level, such consensus-forming debate on all issues of significance will also benefit the broader community that will be able to find reasonable, thoughtful, principled, and intelligent explanations for contentious Islamic issues in the community generally. Using Australia's substantial resources in the fields of research, information management, and dissemination will also benefit our many Muslim neighbors, some only now emerging from periods of desperate oppression or poverty.

The general principled development of personal Sharí 'ah law by Muslims will, to the contrary, aid many including those such as Justice Deane who would not then have to speculate on the Muslim community's position on an issue in litigation, but will then have a rich base of well-researched and an argued range of legal opinions and ideas to draw upon to help the development of Australian common law in relation to Muslims. So, on the question: do Muslim Australians have something distinctive to offer its people and land? The answer to this question must be an affirmative "yes." Consensus is an important source and foundational aspect of Muslim law. Providing practical working examples of how this consensus building can take place - freely, with diversity, with vigor, and yet with respect for the laws and jurisprudence of both Islam and of Australia - will be a great boon to this land and its peoples. 


\section{Notes}

1. The term traditional Muslim is used here in the context of people adopting the Muslim faith of their families and as opposed to those who adopt the faith - generally as adults, and of their own volition, although those who are required to convert, say for the purposes of marriage - are also included in this nontraditional category for the purposes of this paper.

2. It is not suggested that the presence of Islam on this continent is new; it is not - consider Peta Stephenson, Islam Dreaming: Indigenous Muslims in Australia (Sydney, Australia: UNSW Press, 2010). A brief history of Islam in Australia is examined below. Most immigrant Muslim cultures have in the past largely melted into the mainstream.

3. Australian Associated Press, "Fred Nile's Bill to ban the burqa to be debated," The Telegraph (Sydney, June 23, 2010), www. dailytelegraph.com.au/news/fred-niles-bill-to-ban-the-burqa-to-bedebated/story-e6freuy9-1225883022348.

4. Agence France Presse, "Une majorité de Français seraient favorables à une loi interdisant le voile intégral en France," Le Monde, January 19, 2010, www.lemonde.fr/societe/article/2010/01/19/unemajorite-de-francais-seraient-favorables-a-une-loi-interdisant-levoile-integrale-en-france_1293519_3224.html.

5. www.onislam.net/english/ask-the-scholar/morals-and-manners/ dress-and-adornment/169916-alternatives-for-french-muslim-girlsafter-hijab-ban.html?Adornment $=$.

6. www.homelandsecurityus.net/countries/australia/sydney_beach_ race_riot_spreads.htm.

7. It is not implied that these despicable acts are the sole provenance of the far right in the West alone. Churches, synagogues, mosques, businesses, schools, and even kindergartens in Muslim majority states have been targeted and have resulted in loss of life and property and have received extensive injuries or damage. While a majority of Muslims appear to disown such criminal acts, they either seem powerless or unwilling to actively oppose such acts. (Muslim governments, mostly despotic regimes themselves have mostly cracked down on dissent that have threatened their own power structures, mostly but not always successfully in the recent past as seen with the peoples' power movements in the so-called Arab Spring.)

8. Racial Discrimination Act (Commonwealth of Australia) 1975 incorporates into Australian domestic legislation the law, The International Convention on the Elimination of All Forms of Racial Discrimination, that was opened for signature on December 21, 1965 and entered into force on January 2, 1969. 
9. The Australian Constitution. Section 116.

10. Peta Stephenson, The Outsiders Within: Telling Australia's Indigenous - Asian Story (Sydney, Australia: UNSW Press, 2007), 42. Stephenson, Islam Dreaming.

11. Tom Campbell, The Legal Theory of Ethical Positivism (Brookfield, VT: Dartmouth, 1996).

12. The terms Islamic law and Sharī' $a$ h are used interchangeably.

13. The shortcomings of a positivist approach can be seen with respect to systems of law such as the Nazi legal system and are acknowledged: Ronald Dworkin, Laws Empire (Cambridge, MA: Belknap Press, 1986), 104. However, as a universally recognized legal tradition that has stood the test of centuries, this critique arguably cannot reasonably be brought to bear on the Sharī'ah - although no doubt there is a tiny minority who would undoubtedly hold this view, perhaps a view it is posited held on emotion rather than one based on objective fact.

14. Sami Zubaida, Law and Power in the Islamic World (London: I B Tauris, 2003), 23.

15. Ahmad Hassan, The Doctrine of Ijma' in Islam: A Study of the Juridical Principle of Consensus (Islamabad, Pakistan: Islamic Research Institute, 2002), 4.

16. Taha Jabir al-Alwani, Source Methodology in Islamic Jurisprudence (Herndon, VA: The International Institute of Islamic Thought, 2003), 4. Taha Jabir Al-Alwani, Towards a Fiqh for Minorities (Herndon, VA: The International Institute of Islamic Thought, 2003), 19. AlAlwani also aptly describes the dependent sources of Islamic law as the disputed sources of Islamic law. Ibid. The dependent sources used in this paper are:

qiyas - Wael B. Hallaq,"Non-Analogical Arguments in Sunni Juridical Qiyas," in Islamic Law and Legal Theory, ed. E. Edge (Aldershot, UK: Dartmouth, 1996), 205.

ijma' - Hassan, The Doctrine of Ijma' in Islam, 4;

'urf (custom) - Rudolph Peters, Jihad in Classical and Modern Islam (Princeton, NJ, Markus Wiener, 1996), 19. Ahmad al-Raysuni, Imam al-Shatibi's Theory of the Higher Objectives and Intents of Islamic Law (London, The International Institute of Islamic Thought, 2005), 57.

17. As the Shari' ${ }^{-}$ah is a religious law, not all transgressions provide for temporal sanctions. Some of the most serious breaches such as denial of a God or neglect of the ritual prayer are either punishable or may be forgiven at God's discretion but in the hereafter. 
18. Islamic law has a much more sophisticated set of classes of action that goes beyond the lawful-unlawful dichotomy: Kecia Ali, Sexual Ethics and Islam (Oxford: Oneworld Publications, 2006), xxi. However the use of this scale is not directly relevant here and the lawful-unlawful split of action suffices and will be employed.

19. Zubaida, Law and Power in the Islamic World, 107.

20. Ibid.

21. Muhammad ibn Idris al-Shaf'i, Treatise on the Foundations of Islamic Jurisprudence (Cambridge, UK: Islamic Texts Society, first published 1961, 2nd ed, n.d), 333.

22. Zubaida, Law and Power in the Islamic World, 23. The Arabic term for probably correct is zann. According to Imran Ahsan Khan Nyazee [Islamic Jurisprudence (Kuala Lumpur, Malaysia: The Other Press, 2003), 58], the distinction between fard and wajib is most evident in the Hanafi School.

23. Edna Boyle-Lewicki, "Need World's Collide: The Hudad Crimes of Islamic Law and International Human Rights" (2000) New York International Law Review 13: 43-62; Hassan, The Doctrine of Ijma' in Islam, 18.

24. Javad Nurbakhsh, Traditions of the Prophet (New York, KhaniqahiNimatullahi, 1981), 47.

25. Wael B. Hallaq, "Was the Gate of Ijtihad Closed?" (1984) 16 International Journal of Middle Eastern Studies 16 (1984): 10-12.

26. Ibid.

27. Ibid.

28. For example President Hafiz al-Asad, an Alawi, completed the minor pilgrimage to Mecca, a city to which, under Islamic law, Saudi authorities do not permit access for non-Muslims: A. I. Ahram, (2002), "Iraq and Syria: The Dilemma of Dynasty," Middle East Quarterly 9, no. 2 (2002): 33-42.

29. Zubaida, Law and Power in the Islamic World, 104.

30. December 2011 AC saw in the dawn of the new Islamic year 1433 $\mathrm{AH}$.

31. The following extract reflects this largely - though not entirely negative-self-identification:

A true salafi is not of the khawarij who consider most Muslims to be kafirs (disbelievers) because of committing sins. He is not of the shia who revile the Companions (sahabah), who claim that the Qur'an has been altered, who reject the authentic sunna, and who worship the Prophet's family. He is not of the qadariyyah who deny qadar (the Divine Decree). He is not of the murjiah who claim that faith (iman) is only words without deeds. He is not of the mu'attilah who 
deny God's Attributes. He is not of the sufis who worship graves and claim Divine incarnation. He is not of the muqallidun [one who follows taqlid or precedent] who insist that every Muslim should adhere to the madth'hab (School) of a particular imam or sheikh, even when that madth'hab conflicts with the clear texts of the Qur'an or authentic Sunna. Thus the true salafs are ahl us-sunnati wal-jamaah. They are at-ta'ifat ul-mansurah (the Aided, Victorious Group) and al-firqat un-najiyah (the Saved Party) which have been described in several hadiths. (www.qss.org/articles/salafi/text.html)

32. The Qur'ān refers to the followers of Prophet Mohammad, and is a term accepted universally by Muslims, as "Muslims" (Qur'ān 22:78). The noun muslim (which derives from the same root as Islam. in Arabic is masculine, singular. In its general English usage, the word covers both the male and the female, respectively muslim and muslima. The plural used in this paper is the anglicized plural Muslims and will be used to represent the Arabic, muslimoon (male) and muslimaat (female). Further, the term Sunni (Muslim or Islam) used in this paper refers to the four major recognized Sunni schools. The term Shi' $a h$ (Muslim or Islam) refers to the Jafiri or Twelver and the two other recognized Shi' ah schools. The generic English term Muslim as used here includes Sunni and Shī'ah, male and female Muslims.

33. Orientialism and Wahhabism while at two ends of the spectrum (and while there are some exceptions to this observation) appear to have a similar approach in that they seem to be goal-oriented views of text and history: See Wael B. Hallaq, "The Quest for Origins or Doctrine? Islamic Legal Studies as Colonialist Discourse" UCLA Journal of Islamic and Near Eastern Law 2 (2002): 1. Professor Hallaq refers to among several other Orientalist's work - for example. to the "distorted evidence and twisted reasoning" and shallow analysis of Professor Crone's work (ibid., 9) and is also critical of Professor Schacht's work (ibid, 18).

Some contemporary material is also quite self-serving and goalorented: Wael B. Hallaq, A History of Islamic Legal Theories (Cambridge, UK, Cambridge University Press, 1997), 174; Khaled Abou El-Fadl, The Great Theft: Wrestling Islam from the Extremists (New York, HarperCollins, 2005), 26; Khaled Abou ElFadl, Speaking in God's Name: Islamic Law, Authority and Women (Oxford, Oneworld Publications, 2001), 17; Michael Mumisa, Islamic Law: Theory and Interpretation (Beltsville, MD: Amana, 2002), 51; Anne Elizabeth Mayer, "Islam and the State," Cardozo Law Review 12 (1991): 1015, 1025. The term instrumental use of law is used in the sense - and while not endorsing his general views on terrorism and their causes - as characterized in Michael Ignatieff, 
The Lesser Evil Political Ethics in the Age of Terror (Princeton, Princeton University Press, 2004), 123:

adjusting religious doctrine to rationalize the terrorist goal, rather than subjecting it to the genuine interrogation of true faith. and such use of law can also be unabashedly result-oriented and disingenuously selective. El-Fadl, Speaking in God's Name, 172.

34. Roberto Tottoli, Biblical Prophets in the Qur'an and Muslim Literature (Richmond, UK: Curzon, 2002), 182

35. Ayesha M Imam, "Muslim Religious Right ('Fundamentalists') and Sexuality," in Women and Sexuality in Muslim Societies, ed. P Ilkkaracan (Istanbul, Turkey, New Ways, 2000) 121, 128.

36. Quran (33:13), in the context of homes whose protection from the enemy some people used in order to avoid defending the town. Qur'ān (24:58) describes three periods of privacy when people may in the privacy of their rooms, be in a state where their awra may not be fully covered, and persons other than spouses should knock and seek permission before entering.

37. Milton J Cowan, ed., The Hans Wehr Dictionary of Modern Written Arabic (Beirut, Lebanon, Libraire du Liban, 1980), 656.

38. Mohammad Asad, The Message of the Qur'ān (Gibraltar, Dar AlAndalus, 1984), 538-39.

39. Qur'ān 24:31.

40. Katherine Bullock, Rethinking Muslim Women and the Veil (Herndon, VA, International Institute of Islamic Thought, 2002), xl.

41. Wael B Hallaq, "Was the Gate of Ijtihad Closed?" International Journal of Middle Eastern Studies 16 (1984): 3.

42. While some may dispute this assertion that this paper argues that the variety of Islamic dress that has been adopted in the Muslim world is indicative, of at least on the facts, a case for the absence of a consensus.

43. Hold to forgiveness; command what is right; but turn away from the ignorant.

(Qur'ān 7:199)

The phrase wa'mur bil 'urfi (to command what is right) is used in a context different from custom in the everyday contemporary legal meaning. In this context, however, etymologically custom is by the fact "right" - as the words ma'rouf (good), 'arafa (to know) and 'urf share common triliterals - and provides a legal basis for retaining what is good and abrogating bad custom, that is, custom that is explicitly contrary to prohibitions in the Qur'ān and the Sunnah. The 
qualifier dependent as mentioned, signifies accordance with Islamic notions of justice and further must not be contrary to the accepted laws based on the Qur'ān and Sunnah.

44. Article 38(1)(b) of the Statute of the International Court of Justice.

45. Peters, Jihad in Classical and Modern Islam, 19. Ahmad al-Raysuni, Imam al-Shatibi's Theory of the Higher Objectives and Intents of Islamic Law (London, The International Institute of Islamic Thought, 2005), 57.

46. Cherif Bassiouni and Gamal M Badr, "The Shari'ah: Sources, Interpretation, and Rule-Making," UCLA Journal of Islamic and Near Eastern Law 1 (2002): 135, 141. Anas bin Malik accepted the prevailing customary law of Medina, and Abu Hanifa used the custom ( 'urf) that was "recognizably good": Taha Jabir al-Alwani, Source Methodology in Islamic Jurisprudence (Herndon, VA, The International Institute of Islamic Thought, 2003), 27.

47. The Quraysh were the main tribe of Mecca and to which the Prophet and the early caliphs belonged. Some Sunni Muslims hold that the Caliph of the Muslim world must be from this tribe. Shī'ah Muslims implicitly accept this position on the leadership of the Quraysh as the rightful imam should according to the Shi' 'ah schools be descended through the daughter of the Prophet and Ali, her husband and the fourth orthodox Caliph.

48. Peters, Jihad in Classical and Modern Islam, 19. Anas bin Malik, the eponym of the Sunni Maliki School, accepted the prevailing customary law of Medina: al-Alwani, Source Methodology in Islamic Jurisprudence, 27.

49. Maryam Kabeer Faye, Journey through Ten Thousand Veils (Somerset, NJ: Tughra, 2009), 115, describes the comingling of the legal traditions as inseparable.

50. Muhammad Baqir As-Sadr, Lessons in Islamic Jurisprudence (North Haledon, NJ: IPI, 2005), 2.; Wael B. Hallaq, The Origins and Evolution of Islamic Law (Cambridge, UK: Cambridge University Press, 2005), 4, contests the view that the borrowing was heavy, pointing to a vibrant pre-Islamic Arab legal culture, though this does not substantially affect the key factor that Islamic law drew upon custom. El-Fadl, Speaking in God's Name, 35.

51. Zubaida, Law and Power in the Islamic World, 220. Noel J Coulson, Conflicts and Tensions in Islamic Jurisprudence (Chicago, University of Chicago, 1969), 4.

52. Zubaida, Law and Power in the Islamic World, 107.

53. Ibid., 115. M. B. Hooker, Adat Laws in Modern Malaya: Land Tenure, Traditional Government and Religion (Singapore, Singapore 
University Press, 1972). Adat is customary Malay law. Mohd Daud Bakar, ed, The Mejelle: Being an English Translation of Majallah ElAhkam-I-Adliya and A Complete Code of Islamic Civil Law (Kuala Lumpur, Malaysia, The Other Press, 2001); M. B. Hooker, Islamic Law in South East Asia (Leiden, The Netherlands: Brill, 1996), 14.

54. The following are two anecdotal examples of the behavior of Muslims promoting distrust. In the first case, a young Muslim woman in hijab reflected at a public gathering that she was approached by a non-Muslim woman in summer and who had inquired whether she was hot in "all that gear." For whatever reason the Muslim woman answered, "Yes but you are going to hell and it is a lot hotter there." While it is unfortunate that some Muslims do not take the opportunity to engage more positively, and this is clearly their right to do this, what was more disheartening was that many in the audience, including older people, clapped and cheered the woman's answer. In another example, two Muslim women in hijab had parked in a disabled parking spot (when not entitled to do this) and a dispute that arose between a disabled man and the two Muslim women, and the dispute degenerated into the issue of the hijab. It is not suggested however, that any one side bears the responsibility for better communal relations or that these two isolated examples are indicative of the general behavior of Muslim women.

55. For an excellent discussion of the methodology, see Ahmad alRaysuni, Imam al-Shatibi's Theory of the Higher Objectives and Intents of Islamic Law (London, International Institute of Islamic Thought, 2005).

56. Wan Azhar Wan Ahmad, "Public Interests (Al-Masalih AlMursalah)," in Islamic Jurisprudence: An Analysis of the Concept in the Shafi'i School (Kuala Lumpur, Malaysia: International Institute of Islamic Thought, 2003), 9; Bernard K Freamon ["Martyrdom, Suicide, and the Islamic Law of War: A Short Legal History" (2003) Fordham International Law Journal 27 (December 2003): 299, 361] states that "All Islamic scholars agree that the achievement of justice is the pre-eminent "cause of God."

57. The Qur'ān states in 25:33 that Qur'ān is its own best guide (ahsana tafsiir).

58. Qur'ān 10:59; Qur'ān 42:21.

59. Amina Wadud [Inside the Gender Jihad: Women's Reform in Islam (Oxford, Oneworld Publications, 2006), 197] cites the English translation of a hadith that quotes the famous saying by the fourth orthodox Caliph Ali that "[the Qur'ān] needs interpreters, and the interpreters are human beings."

60. It can seem paradoxical that the Qur'ān is a guide for those with taqwa. One could argue that it is those without taqwa who are those 
most in need - although the with-taqwa view fits in with the notion of free will, and it is those with taqwa who are predisposed to using their free will correctly, and are thus the ones who will seek and follow guidance.

61. The term hudal lil moutaqueen (Qur'ān 2:2: this phrase can be translated as "the Qur'an is a guide for to those who prepossess righteousness or taqwa). Further, the word taqwa (or related words to this effect) appear seventy-nine times in the Qur'ān, indicating the centrality of the term taqwa as a technical term in Islamic law.According to E. W. Lane [Arabic English Lexicon, vol. 1 (Cambridge. U.K: Islamic Texts Society, 1984)] the word taqwa is used to describe one who is guarded, alert, cautious, and has a reverential fear of God. To these qualities, the Qur'ānic definition adds the quality of birr. The Qur'ān (91:7) notes that all humans possess a soul and a proportion and order given to it, and further that "an enlightenment as to its wrong and its right" (Qur'ān 91:8). The word used for right is taqwa; the word used for wrong is fujur. The term fujur is employed to describe those who live immorally: Cowan, ed., The Hans Wehr Dictionary of Modern Written Arabic, 697.

62. Lane, Arabic English Lexicon, vol. 1 describes those possessing birr as those who are good, kind, gentle, and obedient to their creator. For Muslims in contemporary Western societies, issues of social justice have appeared to taken a back seat as compared with issues such as dress, rituals around hygiene, and ritual slaughter of food animals have taken center stage in popular discussions.Nevertheless, issues such as civil liberties also touch Muslim communities deeply. Muslims who are arrested or charged gain very little help from the broader Muslim community, about which many in the Australian Muslim community are privately critical; it appears happy to abandon individuals to a system about which they are privately critical, but simply to assert well-rehearsed mantras on their own fidelity to the nation state and that "Islam is a peaceful religion." Muslims in majority states appear to be much more focused on political, justice, and economic equity issues, and issues such as dress appear never to be discussed, with women in various degrees of cover taking part in the demonstrations and rallies calling for change. It might be argued that participating in the hijab debate compounds this problem. However, dress is only one issue; I hope to promote debate on all important subjects using the freedoms that Muslims enjoy in the West.

63. Qur'ān 2:177.

64. That is, facing Mecca from whichever direction, an allusion to the Muslim direction of prayer in canonical worship.

65. Belief in the angels is common to all the surviving Abrahamic faiths. In the Islamic tradition, angels are not possessed of free will. Note 
that Satan in Islam is a djinn and not a fallen angel. See generally the transcripts of ABC Radio National Program Encounter, November 5, 2006, www.abc.net.au/rn/encounter/stories/2006/1771984.htm.

66. Qur'ān 33:59.

67. See endnote reference number 54 above in the text.

68. All Australian states and territories, and the Commonwealth constitute separate jurisdictions.

69. Australian Associated Press, "New burqa, niqab ID laws unveiled in NSW," March 5, 2012, http://news.ninemsn.com.au/ national/8429828/new-burqa-niqab-id-laws-unveiled-in-nsw.

70. Australian Associated Press, "Australian Judge orders witness to remove niqab," The Guardian, August 19, 2010.

71. Australian Associated Press, "New burqa, niqab ID laws unveiled in NSW," March 5, 2012.

72. Pursuant to s.171(4)(b) of the Criminal Procedure Act 2004 (WA), a suppression order was issued by the presiding judge in relation to these matters. As this order remains in force, release the requested transcript will not be possible until the further order of the court.

73. Zubaida, Law and Power in the Islamic World, 14.

74. Hassan, The Doctrine of Ijma' in Islam, 28. Mamdouh Habib (with Julia Collingwood) in My Story (Melbourne, Scribe, 2008), wrote "the tale of a terrorist who wasn't (20)."

75. Ahmad Hasan, "Al-Shaf's Role in the Development of Islamic Jurisprudence" in Islamic Law and Legal Theory, ed. Edge, 415.

76. Hassan, The Doctrine of Ijma' in Islam, vi.

77. Hasan, "Al-Shafi's Role in the Development of Islamic Jurisprudence," 414; Mohd. Hameedullah Khan, The Schools of Islamic Jurisprudence: A Comparative Study, 2nd ed. (New Delhi, India: Kitab Bhavan, 1997), 40.

78. Georges F Hourani, 'The Basis of Authority of Consensus in Sunnite Islam," in Islamic Law and Legal Theory, ed. Edge, 155. Hunt Janin and Andre Kahlmeyer, Islamic Law: The Sharia from Muhammad's Time to the Present (Jefferson, NC: McFarland, 2007), 20.

79. See text accompanying endnote reference number 21.

80. The meaning of "overwhelming majority" has not been judicially determined; it must, however, mean that it excludes a simple majority, and perhaps an overwhelming majority of the Muslims although the overwhelming majority of a legal school might be acceptable on certain less crucial issues. That is, as in the process of idjma' formation, the opinion on an issue of an overwhelming majority of Muslims in that locality should be considered the "correct opinion." 
81. Fatima Mernissi, Dreams of Trespass: Tales of a Harem Girlhood, (Reading, MA: Addison-Wesley, 1994), 100.

82. Bilal Cleland, The Muslims in Australia: A Brief History (Melbourne, Australia: ICV, 2001), 3.

83. Samantha Faulkner with Ali Drummond, Life B 'long Ali Drummond: $A$ Life in the Torres Strait (Canberra, Australia: Aboriginal Studies Press, 2007).

84. Stephenson, Islam Dreaming, 62.

85. Tariq Ramadan, Western Muslims and The Future of Islam (Oxford, Oxford University Press, 2003).

86. It is unclear whether "regularly" in this context equates to the term full time employed by Bullock, (a much less ambiguous term): Bullock, Rethinking Muslim Women and the Veil , 236. While it is difficult to be definitive, but one would expect, it appears anecdotally that the take up of hijab among female converts appears to be significantly higher than the general Muslim population. Other than problems with their immediate non-Muslim families few, if any, have reported any harassment in public. Source: an unpublished survey conducted by the Australian Muslim Civil Rights Network. A common question posed to Muslim converts generally appears to be "Why have you joined these people?" and this provides an opportunity to engage with curious and intelligent people.

87. Again, the uptake by Muslim convert women of the niqab appears to be higher than that of the general Muslim population.

88. Abul ala Maududi, Islamic Law and Constitution, 11th ed. (Lahore, Pakistan: Islamic Publications, 1992), 146.

89. Fatima Mernissi, Women and Islam: A Historical and Theological Enquiry (Oxford, Blackwell, 1991), 96.

90. Ibid., 13.

91 See "Local Dress Customs" below.

92. The dependent sources of law include ijma (consensus), quyas (analogy), urf (custom), and maslaha (public benefits).

93. Bullock cites this prophetic hadith as:

Abu Dawud has transmitted on the authority of A'isha [the Prophet's wife] [that] Asma' the daughter of Abu Bakr [and A'isha's sister], once came up to the Prophet (peace be upon him) wearing transparent clothes. The Prophet (peace be upon him) turned his face away from her and told her, "Asma', when a women begins to menstruate, nothing should be seen of her except this and this," and pointed to his face and hands.

Bullock, Rethinking Muslim Women and the Veil, 232. 
94. See the "Definitions" on page 113.

95. Bullock, Rethinking Muslim Women and the Veil, 200. Clearly, the covering material must also not be transparent:

Abu Dawud has transmitted on the authority of A'isha [the Prophet's wife] [that] Asma' the daughter of Abu Bakr [and A'isha's sister], once came up to the Prophet (peace be upon him) wearing transparent clothes. The Prophet (peace be upon him) turned his face away from her and told her, “Asma', when a women begins to menstruate, nothing should be seen of her except this and this," and pointed to his face and hands.

Bullock, Rethinking Muslim Women and the Veil, 232.

96. Qur'ān 24:31.

97. Muhammad Al-Mughirah al-Bukhari, The Translations of the Meaning of Sahih al-Bukhari vol 7 (Chicago, Kazi, 1976), 454, 551.

98. Abu'l Hussain Muslim, Al Jami'us Sahih, 4 vols. (Beirut, Lebanon: Far-al-Arabia, 1972).

99. Malik ibn-Anas, The Beaten Path Al-Muwatta' (New Delhi, India: Kitab Bhavan, 1979).

100. El-Fadl, Speaking in God's Name, 224.

101. Malik ibn-Anas, The Beaten Path Al-Muwatta' (New Delhi, India: Kitab Bhavan, 1979), 382.

102. Ali persuasively argues that although the question of dress is not the central issue of this date that it is nonetheless important to address these issues and this paper defers to this opinion: Ali, Sexual Ethics and Islam, xvii.

103. Qur'ān 24:31.

104. Qur'ān 4:23.

105. See:

Abu Dawud has transmitted on the authority of A'isha [the Prophet's wife] [that] Asma' the daughter of Abu Bakr [and A'isha's sister], once came up to the Prophet (peace be upon him) wearing transparent clothes. The Prophet (peace be upon him) turned his face away from her and told her, “Asma', when a women begins to menstruate, nothing should be seen of her except this and this," and pointed to his face and hands.

Bullock, Rethinking Muslim Women and the Veil, 232.

If the hadith was taken literally, and the face and hands issue applied to Asma, as being in the presence of a person to whom marriage was not permitted; this would make the argument for niqab more compelling. Such an interpretation is not supported in the literature and is not supported in this paper.

106. Qur'ān 5:6. 
107. UN Secretary-General's Statement, December 1, 2000 (Press Release No: SG/SM/7649OBV/188).

108. See generally S. Cotton, Silent Terror: A Journey in Contemporary African Slavery (New York, Harlem River, 1999); K. Bales, Disposable People: New Slavery in the Global Economy (Berkeley, CA, University of California Press, 1999).

109. Qur'ān 4:25.

110. Qur'ān 24:30.

111. Qur'ān 24:31.

112. Qur'ān 109:6. The Qur'ān and Sunnah recognize many different levels of faith in people, reserving its highest place for those who exercise their free will without fear of hell or seeking rewards in heaven but purely worshipping in an altruistic sense: Izzeddin Ibrahim and Denys Johnson-Davies, Forty Hadith Qudsi (Beirut, Lebanon: Dar-al-Koran, 1991), 65. Muslims are, however, urged to enter into and to perform their covenantal obligations wholeheartedly: Qur'ān $2: 208$. This at minimum must mean that they do not intentionally breach their $u s \underline{u} l$ obligations: see discussion in Zubaida, Law and Power in the Islamic .

113. Please refer to the hadith where the Prophet, notwithstanding his both prophetic and familial authority over Asma, does not order change but merely suggests what is appropriate. Even in a fairly extreme case where the lady's clothes were said to be quite transparent:

Abu Dawud has transmitted on the authority of A'isha [the Prophet's wife] [that] Asma' the daughter of Abu Bakr [and A'isha's sister], once came up to the Prophet (peace be upon him) wearing transparent clothes. The Prophet (peace be upon him) turned his face away from her and told her, "Asma', when a women begins to menstruate, nothing should be seen of her except this and this," and pointed to his face and hands.

Bullock, Rethinking Muslim Women and the Veil, 232.

114. Qur'ān 3:104 includes the relevant phrase, ya'muru na bil ma'ru fi wa yanhauna 'anil munkar (commanding right and forbidding wrong). For an in-depth analysis of this command, please refer to Michael Cook, Commanding Right and Forbidding Wrong in Islamic Thought (Cambridge, UK: Cambridge University Press, 2001).

115. Qur'ān 24:30.

116. There is no implication that these decisions are formulated on any particular knowledge base or under the discipline of legal methodology. In fact, the general level of Islamic knowledge in Australia could reasonably be classified as poor. Knowledge of Islam is not a criterion for immigration to Australia so any 
knowledge of Islam among immigrants is quite incidental. Few Australian educational institutions of higher learning provide formal training in Islamic studies and none in Islamic law. Hodjas (hocas)/ imams/prayer leaders at Sunni Muslim mosques are usually funded and educated by overseas institutions such as Diyanet leri Bakani in Turkey or the Medina University trained Saudi Arabian funded hodjas / prayer leaders from various states. Many Saudi trained hodjas are not fluent in either English or Turkish. Turkish trained hodjas are usually fluent in both Turkish and English, but until recently, their sermons or lectures, traversed very basic, primarily spiritual issues that avoided the practical manifestations of faith and that arguably fitted well into a secular society, the prevailing ideology in Turkey. In Australia, Sh'`‘ah Muslim mosques - which cater for about 40 percent of the Muslims in the large urban centers and growing with the refugee flows from Iraq and Afghanistan, largely cater for Arabic speaking Lebanese immigrants, a large Iraqi refuge population, and a number of Persian Gulf Arab students who appear fearful to return to Sunni ruled states, but whose sermons carry a very diverse range of relevant and contemporary subjects, although not easily accessible by the vast majority of Australian Muslims who are not Arabic speaking.

117. Ayesha M Imam, "Muslim Religious Right ('Fundamentalists') and Sexuality," in Women and Sexuality in Muslim Societies, ed., P. Ilkkaracan (Istanbul, Turkey, New Ways, 2000) 121, 129.

118. North Sea Continental Shelf Cases [Federal Republic Germany v Denmark; Federal Republic Germany v Netherlands] [1969] International Court of Justice Reports 3, 16.

119. See discussion associated with endnote reference number 81 above. 120. Bullock, Rethinking Muslim Women and the Veil, 85.

121. Qur'ān 24:31.

122. See text associated with endnote reference note number 40 above.

123. See text associated with endnote reference note number 54 above.

124. Ali, Sexual Ethics and Islam, xx.

125. Ibid..

126. Roberto Tottoli, Biblical Prophets in the Qur'an and Muslim Literature (Richmond, UK: Curzon, 2002, 182.

127. Qur'ān 24:31 (emphasis added).

128. El-Fadl, Speaking in God's Name, 143.

129. Asad, The Message of the Qur'ān, 538.

130. Qur'ān 2:67-71.

131. Abdur-Rahman I Doi, Women in Shari'ah, 4th ed. (Kuala Lumpur, Malaysia: A. S. Noordeen, 1992), 15; Bullock, Rethinking Muslim 
Women and the Veil, 232, Bullock cites this prophetic hadith as:

Abu Dawud has transmitted on the authority of A'isha [the Prophet's wife] [that] Asma' the daughter of Abu Bakr [and A'isha's sister], once came up to the Prophet (peace be upon him) wearing transparent clothes. The Prophet (peace be upon him) turned his face away from her and told her, "Asma', when a women begins to menstruate, nothing should be seen of her except this and this," and pointed to his face and hands.

132. El-Fadl, Speaking in God's Name, 143-44.

133. Laleh Bakhtiar, Encyclopedia of Islamic Law: A Compendium of the Major Schools, Chicago, ABC, 1996), 76.

134. Asad, The Message of the Qur'ān, 538.

135. Bakhtiar, Encyclopaedia of Islamic Law, 76; See also Zamakshari’s interpretation at text accompanying endnote reference number 131 above.

136. Ibid., 241.

137. Ayesha M Imam, "Muslim Religious Right ('Fundamentalists') and Sexuality," 121, 129.

138. Article 13(3) International Covenant on Economic, Social and Cultural Rights Adopted and opened for signature, ratification and accession by General Assembly resolution 2200A (XXI) December 16, 1966 entry into force January 3, 1976, in accordance with Article 27.

139. For example, Qur'ān 43:23, in which God rejects the argument of people whose main defense was that they (uncritically) followed the religion of their fathers.

140. C. Ward, "The A, B, Cs of Acculturation," in David R Matsumoto, ed. The Handbook of Culture and Psychology (New York: OUP, 2001), 411.

141. That is: Sharī'ah law, jurisprudence, and precedent.

142. Legal necessity, as it is posited in this paper does not reasonably apply to Muslims as a class of persons in Australia

143. Lane, Arabic English Lexicon, vol. 1, 440.

144. Cowan, ed., The Hans Wehr Dictionary of Modern Written Arabic, 586.

145. Ibid., 989.

146. Lane, Arabic English Lexicon, vol. 1, 440.

147. Qur'ān 33:59.

148. El-Fadl, Speaking in God's Name, 240.

149. Qur'ān 33:59.

150. Ibid. 
151. The Arabic term dhalika adnaa, where the operative word adnaa is here translated as "convenient," but elsewhere as "conducive" or sometimes as "something that brings near": Cowan, ed., The Hans Wehr Dictionary of Modern Written Arabic, 11. Nevertheless, dhalika adnaa cannot in any event reasonably be construed as a mandatory prescription.

152. Mernissi, The Veil and the Male Elite, 86.

153. ABC Australia TV, Geraldine Doogue, "COMPASS: CRONULLA TO KOKODA,” July 8, 2007, http://www.abc.net.au/compass/ s1973902.htm.

154. Muhammad Hamidullah, Muslim Conduct of State, 3rd ed. (Lahore: Pakistan, Sh. Mohammed Ashraf, 1953), 117; Anne Elizabeth Mayer, Islam and Human Rights: Tradition and Politics (Boulder, CO: Westview Press, 1999), 48.

155. Bullock, Rethinking Muslim Women and the Veil, 95.

156. The motivation for the use or otherwise of hijab by Australian women has not been scientifically polled to date. Given, however, the broad similarities between Canada and Australia, it is posited that the women's motivation is not likely to greatly different to those examined by Bullock: Ibid., 50 .

157. See the discussion above on the Shafi'ì's position on the preferability of the consensus of the masses as compared with the consensus of the jurists alone.

158. Nu Ha Mim Keller, Reliance of the Traveller: A Classic Manual of Islamic Sacred Law (Beltsville, MD: Amana, 1991), 321.

159. Al-Bukhari, The Translations of the Meaning of Sahih al-Bukhari, vol. 7, 468 .

160. Why Wear Niqab?" Muhajabah Magazine, March 7, 2008, www. muhajabah.com/whyniqab.htm.

161. Mr. Sayed, the defendant, was the principal of an Islamic school, the Muslim Ladies College, with which both the Muslim witness in question and the defendant were closely associated.

162. Asad, The Message of the Qur'ān, 538.

163. Wadud, Inside the Gender Jihad, 19.

164. Jane Mulroney, Australian Statistics on Domestic Violence, (Australian Domestic and Family Violence Clearinghouse), 3. www. austdvclearinghouse.unsw.edu.au/PDF\%20files/Statistics_final.pdf.

165. Elizabeth Broderick, "Not So Straightforward: Domestic Violence in Australia," The Alternative Law Journal 36, no.4 (2011): 224.

166. Mernissi, The Veil and the Male Elite; Mernissi, Islam and Democracy: Fear of the Modern World (Cambridge, Perseus, 1992). 
167. Bullock, Rethinking Muslim Women and the Veil, 136.

168. Ibid.

169. Ibid., 95.

170. Al-Bukhari, The Translations of the Meaning of Sahih al-Bukhari, vol. 7, 454 .

171. Qur'ān 2:143 - wa sa ta (midmost). Hassan, The Doctrine of Ijma' in Islam, 40. 